\title{
Latvian Language
}

National Cancer Institute

\section{Source}

National Cancer Institute. Latvian Language. NCI Thesaurus. Code C153998.

An Indo-European Baltic language that is the official language of Latvia. 